\title{
Simple and Versatile Method for Tagging Phenyldiazirine Photophores
}

Hiroyuki Nakashima, Makoto Hashimoto, Yutaka Sadakane, Takenori Tomohiro, and

Yasumaru Hatanaka*

Graduate School of Medicine and Pharmaceutical Sciences, University of Toyama, 2630 Sugitani, Toyama 930-0194, Japan, and Department of Agricultural and Life Science, Obihiro University of Agriculture and Veterinary Medicine, Inada-cho, Obihiro, Hokkaido 080-8555, Japan, and School of Pharmaceutical Sciences, Kyushu University of Health and Welfare, 1714-1 Yoshino-cho, Nobeoka, Miyazaki 882-

8505, Japan

\section{Supporting Information:}




\section{Experimental procedure.}

4-[3-(Trifluoromethyl)-3H-diazirin-3-yl]benzaldehyde (2). Typical synthetic procedure of 2 was as follows. $\mathbf{S b F}_{5}$ : 3-Phenyl-3-(trifluoromethyl)-3H-diazirine ${ }^{1}$ (1, $142 \mathrm{mg}, 0.76 \mathrm{mmol}$ ) was diluted with dichloromethyl methyl ether $\left(30.4 \mathrm{~mL}, 4.42 \mathrm{mmol}\right.$, a suspected carcinogen $\left.{ }^{2}\right)$ was stirred at room temperature under nitrogen. Suspected carcinogens must be manipulated and stored in a designated area of the laboratory. Whenever feasible engineering controls (chemical fume hoods, or isolation cabinets) must be utilized for its manipulations. Lab coat, safety goggles, and gloves are considered the minimum level of protection. $\mathrm{SbF}_{5}(217 \mathrm{mg}, 1.0 \mathrm{mmol})$ in $\mathrm{TfOH}(0.5 \mathrm{~mL}, 1.96 \mathrm{mmol})$ was added dropwise to the mixture. The reaction mixture was stirred for $30 \mathrm{~min}$ and poured into cold water (20 $\mathrm{mL})$ and hexane $(30 \mathrm{~mL})$. The organic phase was washed with brine, and dried over $\mathrm{MgSO}_{4}$. After removal of solvent, the residue was purified by chromatography (hexane : $\mathrm{CH}_{2} \mathrm{Cl}_{2}=2: 1$ ) on silica gel to afford compound 2 as a pale yellow oil $(131 \mathrm{mg}, 80 \%)$. $\mathbf{T i C l}_{4}$ : To a mixture of $\mathbf{1}$ (1.86 $\mathrm{g}, 0.01$ mol) and dichloromethyl methyl ether $(3.45 \mathrm{~g}, 0.03 \mathrm{~mol})$, a yellow solid mass prepared from $\mathrm{TiCl}_{4}$ $(2.85 \mathrm{~g}, 0.015 \mathrm{~mol})$ and $\mathrm{TfOH}(3.00 \mathrm{~g}, 0.02 \mathrm{~mol})$ was added portion wise at room temperature under argon. The reaction was allowed to proceed for $1 \mathrm{~h}$ and quenched with a cold water at $-20^{\circ} \mathrm{C}$. The resulting mixture was neutralized with $\mathrm{Na}_{2} \mathrm{CO}_{3}$ and extracted with hexane. The organic phase was washed with brine, and dried over $\mathrm{MgSO}_{4}$. After removal of solvent, the residue was purified by chromatography (hexane : ether $=4: 1)$ on silica gel to afford compound 2 as a pale yellow oil $(1.71$ $\mathrm{g}, 80 \%)$. The product was identified according to the previous report. ${ }^{3}$

4-[3-(Trifluoromethyl)-3H-diazirin-3-yl]benzoic acid methyl ester (4). $\left(\mathrm{NH}_{4}\right)_{2} \mathrm{~S}_{2} \mathrm{O}_{8}(1.37 \mathrm{~g}, 6$ mmol) was suspended in $85 \% \mathrm{H}_{2} \mathrm{SO}_{4}(1.73 \mathrm{~g})$, and the suspension was added to a solution of compound $2(1.07 \mathrm{~g}, 5 \mathrm{mmol})$ in $\mathrm{MeOH}(10 \mathrm{~mL})$ at $15^{\circ} \mathrm{C}$. The reaction mixture was stirred at $15^{\circ} \mathrm{C}$ for $3 \mathrm{~h}$, and poured into a cold water. The product was extracted with ether, washed with water, and dried over $\mathrm{MgSO}_{4}$. After evaporation of the solvent, the residue was purified by column chromatography on silica gel (hexane : ether $=5: 1$ ) to afford compound 4 as a pale yellow oil $(1.19 \mathrm{~g}, 97 \%) .{ }^{1} \mathrm{H}-\mathrm{NMR}\left(\mathrm{CDCl}_{3}\right) \delta 8.06(\mathrm{~d}, 2 \mathrm{H}, J=9.0 \mathrm{~Hz}), 7.25(\mathrm{~d}, 2 \mathrm{H}, J=9.0 \mathrm{~Hz}), 3.93$ (s, 3H); IR (neat) $1725 \mathrm{~cm}^{-1}$; HRMS m/z calcd. for $\mathrm{C}_{10} \mathrm{H}_{7} \mathrm{~F}_{3} \mathrm{~N}_{2} \mathrm{O}_{2} 244.0460$ found 244.0479 .

4-[3-(Trifluoromethyl)-3H-diazirin-3-yl]benzyl alcohol (5). To a solution of compound 2 (8.5 $\mathrm{g}, 40 \mathrm{mmol})$ in $\mathrm{EtOH}(20 \mathrm{~mL})$ was slowly added a solution of $\mathrm{NaBH}_{4}(1.65 \mathrm{~g}, 44 \mathrm{mmol})$ in EtOH (20 $\mathrm{mL}$ ) at $0^{\circ} \mathrm{C}$, and stirred at room temperature for $4 \mathrm{~h}$. After acidification of the solution with $1 \mathrm{M} \mathrm{HCl}$ at $0{ }^{\circ} \mathrm{C}$, the product was extracted with ether. The solution was died over $\mathrm{MgSO}_{4}$, and the solvent was removed in vacuo to afford compound 5 (8.5 g, quant.) as a pale yellow oil. All spectral data were identical with the previous report. ${ }^{4,5}$ 
4-[3-(Trifluoromethyl)-3H-diazirin-3-yl]benzyl bromide (6). To a solution of compound 5 (8.5 $\mathrm{g}, 39 \mathrm{mmol})$ and $\mathrm{CBr}_{4}(14.6 \mathrm{~g}, 44 \mathrm{mmol})$ in $\mathrm{CH}_{2} \mathrm{Cl}_{2}(40 \mathrm{~mL})$ was slowly added $\mathrm{Ph}_{3} \mathrm{P}(11.5 \mathrm{~g}, 44 \mathrm{mmol})$ at $0{ }^{\circ} \mathrm{C}$. The mixture was stirred at room temperature for $4 \mathrm{~h}$. After addition of hexane $(200 \mathrm{~mL})$ to the solution, the precipitate was removed by filtration over celite. The filtrate was evaporated in vacuo, and the residue was purified by column chromatography on silica gel (hexane : ether $=1: 1$ ) to afford compound 6 (10.9 g, quant.) as a pale yellow oil. All spectral data was identical with the previous report. ${ }^{6}$

By another synthetic procedure was also given compound $\mathbf{6}$ directly from compound $\mathbf{1}$ as follows. To a solution of compound $1(5.2 \mathrm{~g}, 28 \mathrm{mmol})$ and bromomethyl methyl ether $(6.9 \mathrm{~g}, 55 \mathrm{mmol})$ was added $\mathrm{TfOH}(25 \mathrm{~g}, 167 \mathrm{mmol})$ at $-40{ }^{\circ} \mathrm{C}$ under nitrogen. After stirring for $1 \mathrm{~h}$, the mixture was carefully poured into cold water. The product was extracted with hexane twice followed by washing with water three times and brine, and the organic solution was then dried over $\mathrm{MgSO}_{4}$, and evaporated. The residue was purified by chromatography (hexane : ether $=10: 1$ ) on silica gel to afford compound $6(2.2 \mathrm{~g}, 28 \%)$.

\section{$\mathrm{N}$-(Diphenylmethylene)-4-[3-(trifluoromethyl)-3H-diazirin-3-yl]-L-phenylalanine tert-butyl} ester (7). tert-Butylglycinate benzophenone imine $(1.14 \mathrm{~g}, 3.8 \mathrm{mmol})$ and $O$-allyl- $N$-9anthracenylmethylcinchonidium bromide ${ }^{7}(0.213 \mathrm{~g}, 0.35 \mathrm{mmol})$ was dissolved in $\mathrm{CH}_{2} \mathrm{Cl}_{2}(9 \mathrm{~mL})$. The bromide $6(1.42 \mathrm{~g}, 5.1 \mathrm{mmol})$ was added to the mixture and was cooled at $-78^{\circ} \mathrm{C}$. To the solution was slowly added BEMP (1.41 g, $5.1 \mathrm{mmol})$ followed by stirring for additional $7 \mathrm{~h}$. After removal of the solvent, the residue was dissolved in ether. The solution was washed with water twice, brine, and dried over $\mathrm{MgSO}_{4}$. The crude product was purified by column chromatography on silica gel (hexane : EtOAc $=7: 1)$ to afford compound $7(1.89 \mathrm{~g}, 95 \%)$ as a pale yellow oil. ${ }^{1} \mathrm{H}-\mathrm{NMR}\left(\mathrm{CDCl}_{3}\right) \delta 7.55(\mathrm{~d}$, $2 \mathrm{H}, J=8.5 \mathrm{~Hz}), 7.23-7.39(\mathrm{~m}, 6 \mathrm{H}), 7.08(\mathrm{~d}, 2 \mathrm{H}, J=8.5 \mathrm{~Hz}), 7.03(\mathrm{~d}, 2 \mathrm{H}, J=8.5 \mathrm{~Hz}), 6.59(\mathrm{~d}, 2 \mathrm{H}, J$ $=7.4 \mathrm{~Hz}), 4.09(\mathrm{dd}, 1 \mathrm{H}, J=4.4,8.8 \mathrm{~Hz}), 3.21(\mathrm{dd}, 1 \mathrm{H}, J=4.4,13.5 \mathrm{~Hz}), 3.16(\mathrm{dd}, 1 \mathrm{H}, J=8.8,13.5$ $\mathrm{Hz}), 1.43(\mathrm{~s}, 9 \mathrm{H}) ;$ FABMS m/z $494[\mathrm{MH}]^{+}$; HRMS $\mathrm{m} / \mathrm{z}$ calcd. for $\mathrm{C}_{28} \mathrm{H}_{26} \mathrm{~F}_{3} \mathrm{~N}_{3} \mathrm{O}_{2} 494.2055$ found 494.2066.

L-4-[3-(Trifluoromethyl)-3H-diazirin-3-yl]phenylalanine (3). Compound 7 (0.96 g, $1.95 \mathrm{mmol})$ was dissolved in TFA $(15 \mathrm{~mL})$ at $0^{\circ} \mathrm{C}$. The mixture was stirred for $2 \mathrm{~h}$ at room temperature. After evaporation, the residue was partitioned between $\mathrm{CH}_{2} \mathrm{Cl}_{2}$ and $1 \mathrm{M} \mathrm{HCl}$, and was extracted with $1 \mathrm{M} \mathrm{HCl}$ three times. The aqueous solutions were combined and evaporated. The residue was purified by ionexchange column chromatography on Dowex 50W-X8 (Muromachi Technos Co., Ltd., Tokyo) eluted with 5\% ammonium solution. The solution was combined, and lyophilized to afford compound $3(0.52 \mathrm{~g}, 97 \%)$ as a white solid. The product was identified according to the previous report. ${ }^{8}$

\section{$\mathbf{N}$-(9-Fluorenylmethoxycarbonyl)-4-[3-(trifluoromethyl)-3H-diazirin-3-yl]-L-phenylalanine}

(8). To a solution of compound $3(2.00 \mathrm{~g}, 7.3 \mathrm{mmol})$ in $1.0 \mathrm{M}$ sodium hydrogen carbonate $(240 \mathrm{~mL})$ 
was added a solution of FmocOSu $(3.69 \mathrm{~g}, 10.9 \mathrm{mmol})$ in $\mathrm{CH}_{3} \mathrm{CN}(65 \mathrm{~mL})$ and the reaction mixture was stirred at room temperature for 10 hours. After evaporation of $\mathrm{CH}_{3} \mathrm{CN}$, EtOAc was added to the residual solution and $1 \mathrm{M} \mathrm{HCl}$ was added to make $\mathrm{pH}$ less than 1 . The organic phase was washed with brine, and dried over $\mathrm{MgSO}_{4}$. After removal of the solvent, the residue was recrystallized from hexane to afford pale yellow solid $(2.58 \mathrm{~g}, 71 \%)$. The physical data was identified with previous report. $[\alpha]_{\mathrm{D}}+$ $22.4^{\circ}(\mathrm{c}=0.52, \mathrm{EtOH}),+24.84^{\circ}(\mathrm{c}=0.338, \mathrm{EtOH}){ }^{8}$ The optical purity of compound 8 was determined by HPLC using a chiral support (Sumichiral OA-3300 column (4.6 x $250 \mathrm{~mm}$ ), $0.01 \mathrm{M}$ ammonium acetate in $\mathrm{MeOH}$, flow rate $1 \mathrm{~mL} / \mathrm{min}, \lambda=360 \mathrm{~nm}$ ). The $\mathrm{D}$ - and L-isomers were eluted at 11.7 and $12.4 \mathrm{~min}$, respectively. The enantiomeric excess was calculated as $97 \%$ from area ratio of the signals.

Solid-phase synthesis of TmdPhe-CaMBP (9). TmdPhe-CaMBP was synthesized in a $10 \mathrm{mmol}$ scale on Wang-PEG resin by a standard methodology using Fmoc amino acid derivatives. Tryptophan in a 17-residue CaMBP was replaced by TmdPhe. In the final step of the synthesis, biotin was automatically added to the resin to be attached in the N-terminus of the peptide in the same condition as Fmoc amino acid. The synthetic peptide was cleaved from the resin by treatment with TFA : ethanedithiol : thioanisole $=90: 5: 5$ for $2 \mathrm{~h}$. The product was purified by reverse-phase HPLC. MALDI-TOF MS $m / z$ calcd. for $\mathrm{C}_{113} \mathrm{H}_{200} \mathrm{~F}_{3} \mathrm{~N}_{26} \mathrm{O}_{20} \mathrm{~S}[\mathrm{MH}-2 \mathrm{~N}]^{+} 2330.51$ found 2332.19. 


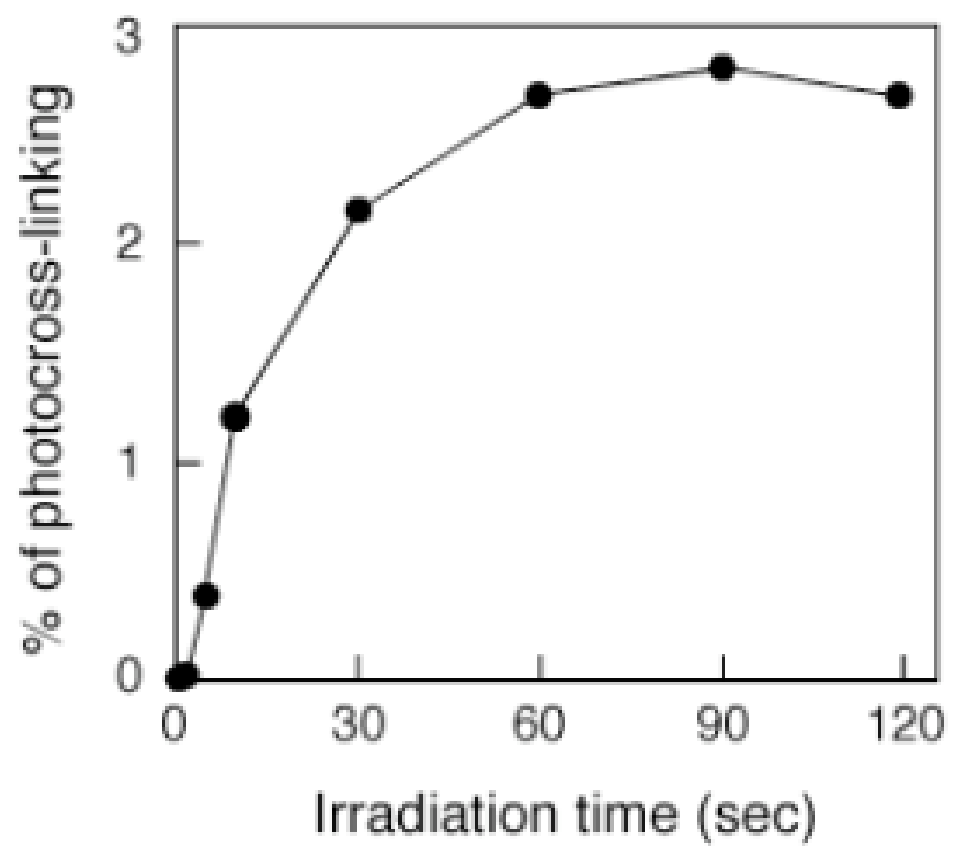

Figure S1. Time course of photolabeling of CaM by TmdPhe-CaMBP.

Figure S1 showed irradiation time-dependent manner for the cross-linking of TmdPhe-CaMBP (9) to CaM. Photolysis of the complex of $9(5 \mu \mathrm{M})$ and CaM $(2.5 \mu \mathrm{M})$ performed by UV-A irradiation with $30 \mathrm{~W} / \mathrm{m}^{2}$ of $360 \mathrm{~nm}$ light at $0{ }^{\circ} \mathrm{C}$ after incubation at $37{ }^{\circ} \mathrm{C}$ for $10 \mathrm{~min}$ in $50 \mathrm{mM}$ Tris buffer $(\mathrm{pH}$ 7.4) containing $\mathrm{CaCl}_{2}(5 \mathrm{mM})$, and $\mathrm{NaCl}(0.15 \mathrm{M})$. After irradiation, photoproducts were chromatographed on reverse-phase HPLC (ODS) with $0.1 \%$ aqueous trifluoroacetic acid using a gradient of $\mathrm{CH}_{3} \mathrm{CN}$ from 40 to $60 \%$.

\section{References}

(1) Brunner, J.; Senn, H.; Richards, F. M. J. Biol. Chem. 1980, 255, 3313.

(2) Van Duuren, B. L.; Katz, C.; Goldschmidt, B. M.; Frenkel, K; Sivak, A. J. Natl. Cancer Inst. 1972, $48,1431$.

(3) Kempin, U.; Kanaoka, Y.; Hatanaka, Y. Heterocycles 1998, 49, 465.

(4) Hashimoto, M.; Hatanaka, Y. Chem. Pharm. Bull. 1999, 47, 667.

(5) Weber, T.; Brunner, J. J. Am. Chem. Soc. 1995, 117, 3084.

(6) Nassal, M. J. Am. Chem. Soc. 1984, 106, 7540.

(7) Corey, E. J.; Xu, F.; Noe, M. C. J. Am. Chem. Soc. 1997, 119, 12414.

(8) Fishwick, C. W. G.; Sanderson, J. M.; Findlay, J. B. C. Tetrahedron Lett. 1994, 35, 4611. 